\title{
PROCES ROZBUDOWY ŚRÓDZIEMNOMORSKICH SIL EKSPEDYCYJNYCH (MEDITERRANEAN EXPEDITIONARY FORCE) W 1915 ROKU
}

\begin{abstract}
Kampania dardanelska miała stanowić krótki epizod i przynieść znaczne strategiczne korzyści dla Ententy. Spodziewano się, że wykorzystanie wojsk lądowych stanowić będzie jedynie ostateczność, w przypadku gdyby okrętom nie udało się przebić na Morze Marmara. Okazało się jednak, że zamiast roli pomocniczej, wojska lądowe musiały przeprowadzić pierwszą w nowoczesnej wojnie operację desantową na bronione wybrzeże. Choć udało się zająć plaże, to nie osiągnięto decydującego sukcesu, a sama kampania zamiast krótkiej ekspedycji przekształciła się w wielomiesięczne walki pozycyjne. Początkowo siły MEF składały się jedynie z 5 dywizji piechoty. $\mathrm{Z}$ czasem ich liczba systematycznie wzrastała, by na przełomie sierpnia/września 1915 roku osiągnąć liczbę 15 dywizji zgrupowanych w czterech korpusach armijnych.

Kolejne wzmocnienia kierowano w ten rejon stosunkowo przypadkowo i wynikało to z pojawiających się możliwości niż wcześniejszego planowania. W rezultacie wzmocnienia docierały pojedynczymi dywizjami, które rzucano do walki i szybko wyczerpywano ich efektywną zdolność bojową. Gdy wyciągnięto wnioski z tego działania i MEF wzmocniono znacznie większymi siłami, pozwalającymi na przewodzenie zakrojonej na szeroką skalę ofensywy. Popełniono kardynalne błędy w doborze wyższej kadry dowódczej oraz ponownie nie przygotowano natychmiastowych uzupełnień oraz rezerw operacyjnych. Brak planowości oraz chaos w zakresie rozbudowy potencjału MEF stanowił jeden z czynników, który ostatecznie zakończył się klęską całej kampanii.
\end{abstract}

Słowa kluczowe: Kampania gallipolijska, Dardanele, Armia Brytyjska, I wojna światowa.

\section{WPROWADZENIE}

Na przełomie 1914/1915 roku wojna w Europie weszła w fazę stagnacji. Żadna z walczących stron nie była w stanie osiągnąć decydującej przewagi nad przeciwnikami. Ponadto ogromne straty w dotychczasowych walkach, wyczerpanie zapasów wojennych oraz powolne tempo przestawiania się na produkcję wojenną sprawiały, że wizja osiągnięcia przełomu na wiosnę i w lecie 1915 roku była mało realna. Wszystkie walczące państwa stanęły przed dylematem wyboru odpowiedniej strategii. Dla Wielkiej Brytanii problem ten był wyjątkowo złożony. Państwo to posiadało stosunkowo nieliczne wojska lądowe, wobec

${ }^{1}$ Dr Paweł Korzeniowski, Instytut Historii, Uniwersytet Rzeszowski; e-mail: korzeniowski. p@gmail.com

Paweł Korzeniowski, PhD, Institute of History, University of Rzeszów; e-mail: korzeniowski. p@gmail.com 
tego możliwości oddziaływania na głównym teatrze wojny, jakim był front zachodni, były niewielkie. Z drugiej strony, Zjednoczone Królestwo posiadało w tym czasie najsilniejszą marynarkę wojenną i niepodzielnie panowało na oceanach. Pod względem strategicznym dawało to możliwość rozpoczęcia działań zbrojnych niemal w każdym zakątku globu. W rezultacie, na początku 1915 roku brytyjskie kierownictwo polityczno-wojskowe ${ }^{2}$ zdecydowało, że wobec braku możliwości zwiększanie bezpośredniej presji na same Niemcy należało skupić się na pośrednim osłabieniu tego państwa, poprzez wyeliminowanie $\mathrm{z}$ wojny jednego z jej sojuszników, a mianowicie Imperium Osmańskiego. Zamierzano to osiągnąć poprzez zaatakowanie osmańskich umocnień broniących Cieśniny Dardanelskiej, i po ich zneutralizowaniu, planowano skierować na wody Morza Marmara eskadrę okrętów wojennych, która miała bezpośrednio zagrozić Konstantynopolowi. Zdaniem brytyjskich polityków i wojskowych, rząd osmański, wobec perspektywy utraty stolicy, miał poprosić aliantów o zawieszenie broni i zgodzić się na separatystyczny pokój. Ponadto opanowanie cieśnin czarnomorskich miało dla państw Ententy przynieść szereg dodatkowych korzyści strategicznych. Zakładano, że tą droga uda się przesyłać znaczne ilości zaopatrzenia dla armii rosyjskiej, która choć liczna, cierpiała na ogromne niedobory w uzbrojeniu. Z drugiej strony, liczono na eksport rosyjskiego zboża, dzięki czemu poprawie ulec miała sytuacja aprowizacyjna Francji i Wielkiej Brytanii. Wreszcie, liczono, że aliancki sukces skłoni neutralne państwa bałkańskie do opowiedzenia się po ich stronie. Ich armie, wykierowane przeciwko Austro-Węgrom miały nie tylko zmniejszyć presję na Serbię ze strony tego państwa, ale wręcz doprowadzić do załamania się armii Habsburgów. Wówczas, osamotnione Niemcy, nie byłyby w stanie długo opierać się siłom koalicji ${ }^{3}$.

${ }^{2}$ Przed wybuchem wojny kwestie związane z planowaniem strategicznym i przygotowaniem do wojny realizował Komitet Obrony Imperialnej (Comittee of Imperial Defence). Formalnie został powołany do życia w 1904 roku, i miał na celu analizowanie zagadnień związanych z obroną imperium oraz stanowić ciało doradcze rządu w kwestiach militarnych. Ponadto do jego kompetencji należało przygotowywanie aktów prawnych dotyczących przygotowania państwa do wojny i przedkładanie ich rządowi. Komitet nie miał stałego składu, poza premierem, który był jego przewodniczącym oraz sekretarza. Ponadto w jego obradach uczestniczyli wybrani członkowie rządu (jeśli omawiana kwestia dotyczyła ich resortów) oraz wysokich rangą oficerów, którzy pełnili rolę ekspertów. Po wybuchu wojny Komitet, uzupełniony m.in. przez przedstawicieli opozycji i kilku wojskowych doradców, przekształcił się w Radę Wojenną (War Council), odpowiedzialną za podejmowanie strategicznych decyzji dotyczących prowadzenia wojny; zob. A. Rawson, The British Army 1914-1918, Stroud 2014, s. 43-46.

${ }^{3}$ Secretary's Notes of A Meeting of A War Council Held At 10, Downing Street, January 13, 1915, War Council, TNA, sygn. CAB 22/1/8, k. 28-32; Nie ma niestety tutaj miejsca na dłuższe analizowanie powyższych założeń. Stwierdzić jednak należy, że były one w zdecydowanej większości pozbawione racjonalnych podstaw. Nawet zakładając, że udałoby się, zgodnie z założeniami, wyeliminować Imperium Osmański z wojny, i opanować cieśniny czarnomorskie, to możliwości transportowe i przeładunkowe rosyjskich portów były ograniczone, co więcej, produkcja wojenna nie pokrywała nawet zapotrzebowania wojsk francuskich i brytyjskich, trudno wiec mówić o możliwości dozbrojenia sił rosyjskich, wreszcie, w Londynie całkowicie nie rozumiano realiów bałkańskich, i siły konfliktów miedzy państwami tego regionu, i wspólne opowiedzenie się ich po stronie Ententy było w praktyce niemożliwe. Szerzej zob. m.in.: W. Churchill, The World Crisis, Vol. 2. 1915, London, New York 2015, s. 27-42, passim; T. Curran, The Grand Deception. Churchill and the Dardanelles, Newport 2015; D. Van Der Vat, The Dardanelles Disaster. Winston Chuirchil's Greatest Failure, London-New York 2009. 
Jak więc widać, wyeliminowanie Imperium Osmańskiego z wojny miało stanowić pierwszy krok na drodze do pokonania II Rzeszy, bez konieczności ponoszenia gigantycznych ofiar w bezpośredniej walce z armią niemiecką, co stanowiło esencję tradycyjnej brytyjskiej strategii prowadzenia wojny. Niestety, na początku 1915 roku wszystkie brytyjskie siły lądowe zaangażowane były we Francji i wycofanie choćby jednej dywizji z tego teatru wojennego nie było możliwe. Stąd zdecydowano, że operacje w rejonie Dardaneli prowadzone będą jedynie przy pomocy sił morskich. Niestety, próby zneutralizowania osmańskich umocnień przez artylerię okrętową kończyły się niepowodzeniem, a próba sforsowania cieśniny podjęta 18 marca 1915 roku, zakończyła się aliancką klęską i utratą 3 okrętów liniowych ${ }^{4}$.

Niepowodzenie to, choć prestiżowo bardzo niekorzystne, militarnie nie miało żadnego znaczenia dla ówczesnej sytuacji strategicznej. Utracone okręty należały do przestarzałych typów, co więcej, wkrótce straty zostały uzupełnione, a nawet zwiększono liczbę okrętów w rejonie Dardaneli. Jednak w Londynie i Paryżu obawiano się politycznych reperkusji związanych z wydźwiękiem, jaki mogła mieć ta porażka w koloniach zamieszkałych przez muzułmanów. Stąd zamiast przerwać całą operację i ograniczyć się do blokowania wejścia do cieśniny, zdecydowano się na przeprowadzenie desantu na Półwyspie Gallipoli. W założeniach siły lądowe miały opanować od strony lądu osmańskie forty i stanowiska artylerii i umożliwić okrętom oczyszczenie wód cieśniny z min i wpłynięcie na Morze Marmara 5 .

W ten sposób doszło do podjęcia decyzji o przeprowadzeniu pierwszego w historii nowoczesnej wojny desantu na bronione wybrzeże. W założeniach miała być to błyskawiczna operacja, której rozstrzygniecie nastąpić powinno w przeciągu trzech dni od lądowania. Te optymistyczne założenia niestety nie zostały zrealizowane i zamiast krótkiej, decydującej kampanii, wojska brytyjskie i francuskie uwikłały się w wielomiesięczne zaciekłe walki, angażujące coraz to nowe dywizje. Niniejszy artykuł ma na celu przedstawienie procesu rozbudowy Śródziemnomorskich Sił Ekspedycyjnych, które początkowo liczyły 5 dywizji piechoty, by w szczytowym momencie składać się z 4 korpusów armijnych liczących w sumie 15 dywizji 6 .

\footnotetext{
${ }^{4}$ Zatopione zostały francuski Bouvet oraz brytyjskie HMS Irresistible oraz HMS Ocean, uszkodzone francuskie Galois oraz Suffren oraz brytyjski HMS Inflexible. Szerzej na temat działań morskich w rejonie Dardaneli patrz: P. Nykiel, Wyprawa do Złotego Rogu. Działania wojenne w Dardanelach i na Morzu Egejskim (sierpień 1914 - marzec 1915), Kraków 2008.

5 C.F. Aspinal-Oglander, Official History of The Great War. Military Operations. Gallipoli. Vol. 1. Inception of the Campaign to May 1915, Heinemann 1929, s. 100-103, passim.

${ }^{6}$ Nie ma tutaj miejsca by dokładnie omówić przebieg walk na Półwyspie Gallipoli od momentu alianckiego desantu w dniu 25 kwietnia 1915 roku do ewakuacji na początku stycznia 1916 roku. Obecnie pracuję nad monografią tej kampanii, która w sposób kompleksowy przedstawi te niezwykle ciekawe, a niemal nieznane w Polsce wydarzenia. Zwięzły zarys walk na półwyspie Czytelnik znajdzie w pracy brytyjskiego autora Petera Harta, poświęconej militarnym działania na frontach I wojny światowej. Choć publikacja ta w wielu miejsca jest mocno niedokładna, to akurat fragmenty dotyczące operacji w rejonie Dardaneli zostały opracowane stosunkowo rzetelnie; patrz P. Hart, I wojna światowa 1914-1918. Historia militarna, Poznań 2013, s. 211-232.
} 


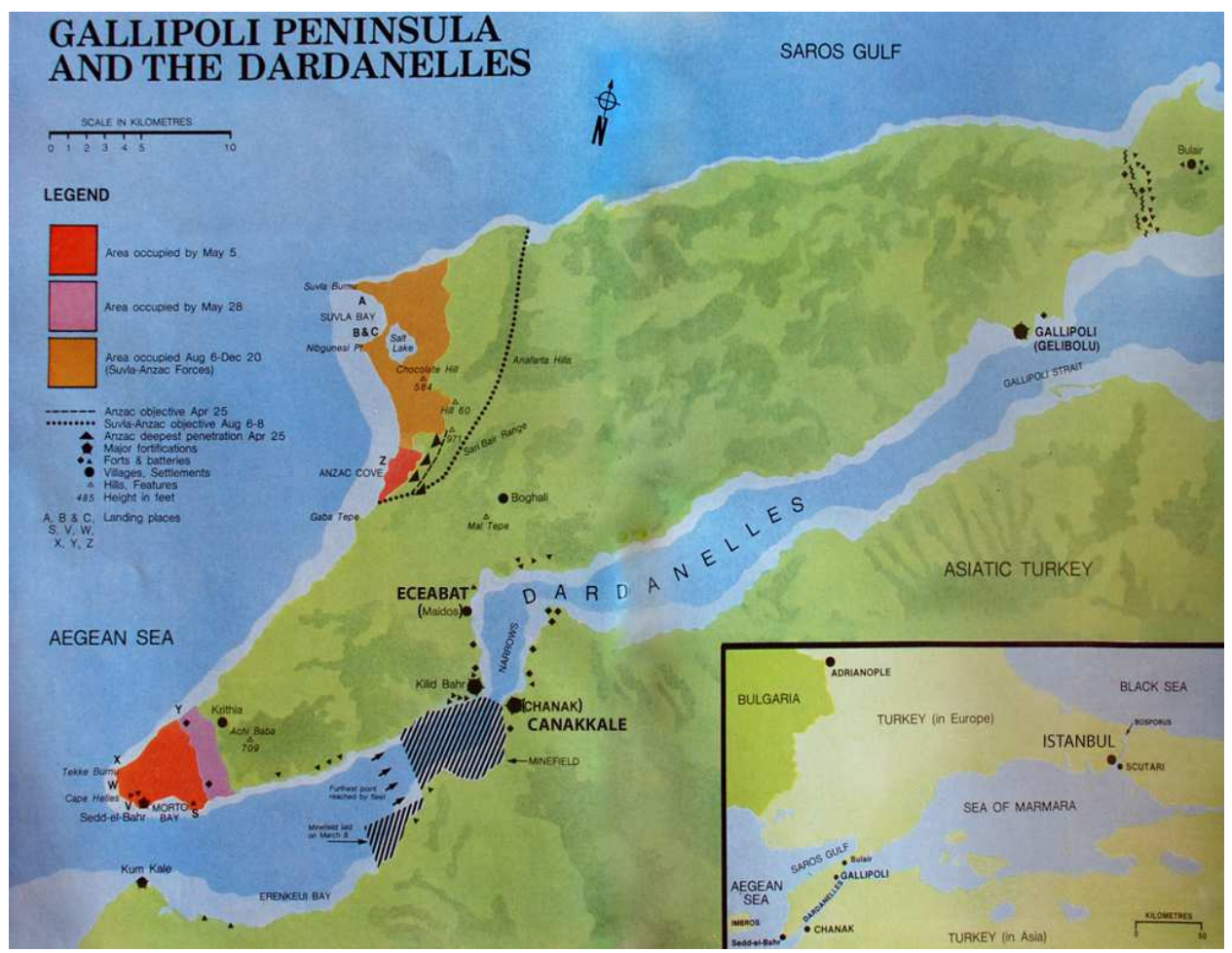

Mapa 1. Kampania na Półwyspie Gallipoli w 1915 roku

Źródło: https://cinetext.files.wordpress.com/2015/12/map1.jpg (dostęp: 1.03.2017 r.).

\section{2. ŚRÓDZIEMNOMORSKIE SILY EKSPEDYCYJNE W KWIETNIU 1915 ROKU}

Operacja desantowa na wybrzeże bronione przez przeciwnika stanowi działanie niezwykle trudne i skomplikowane, nawet w sytuacji, kiedy dysponuje się odpowiednio wyszkolonymi wojskami i sprzętem. Ponadto proces planowania tego typu działań jest bardzo długi i wymaga sprawnego działania sztabów, a sam dowódca musi mieć odpowiednie predyspozycje i cechy charakteru, aby móc skutecznie zrealizować postawiony przed nim cel ${ }^{7}$. Tymczasem sama operacja stanowiła działanie niezwykle improwizowane. Na dowódcę Śródziemnomorskich Sił Ekspedycyjnych (Mediterranean Expeditionary Force - MEF), wyznaczono gen. Iana Hamiltona, który oficjalnie dowiedział się o swojej nominacji 12 marca 1915 roku. W trakcie rozmowy z marsz. Horatio Kitchenerem, Sekretarzem ds. Wojny (Secretary of State for War) usłyszał, że zadaniem sił, oddanych do jego dyspozycji, będzie pełnienie jedynie roli pomocniczej względem działań floty. Zakładano, że osmańskie umocnienia zostaną zneutralizowane ogniem dział okrętowych, po czym obrońcy opuszczą zajmowane pozycje. Stąd wojska lądowe będą miały zadanie jedynie zająć jedynie symbo-

${ }^{7}$ Dodać do tego należy także element zaskoczenia, zarówno co do miejsca, jak i czasu lądowania. Ponieważ działania morskie prowadzono w rejonie Dardaneli od kilku miesięcy, element zaskoczenia został już dawno utracony. 
licznie bronione stanowiska przeciwnika. Nikt wówczas nie planował zakrojonej na szeroką skalę operacji desantowej ${ }^{8}$. Z tego powodu uznano, że wystarczy skierować w rejon Dardaneli siły nie zawsze w pełni przygotowane do działań bojowych. Pamiętać jednak należy, że nawet gdyby Brytyjczycy i Francuzi chcieli wysłać w rejon operacji siły o najwyższych walorach bojowych, to nie dysponowali w tym czasie takimi rezerwami. Wszystkie dostępne siły skierowano na front zachodni, gdzie i tak sytuacja aliansów była trudna. O tym, by wycofać $\mathrm{z}$ tego teatru wojennego choćby jedną dywizję nie mogło być mowy9 .

$\mathrm{W}$ istniejących warunkach zdecydowano, że podstawę MEF stanowić będą oddziały australijskie i nowozelandzkie, które w tym czasie szkoliły się w Egipcie ${ }^{10}$. W grudniu 1915 roku siły te zgrupowano w ramach Australijskiego i Nowozelandzkiego Korpusu Armijnego (Australian \& New Zealand Army Corps - ANZAC), na czele którego stanął gen. William Birdwood. Składały się one z australijskiej 1. Dywizji Piechoty gen. Williama Bridgesa, Nowozelandzkiej i Australijskiej Dywizji Piechoty gen. Alexandra Godleya oraz dwóch brygad kawalerii ${ }^{11}$. Już 4 marca 3. BP dowodzona przez płk. Sinclair-MacLagana wylądowała na Lemnos (dziś gr. Limnos), mając pełnić rolę pomocniczą dla działań floty, która miała wkrótce przystąpić do generalnego ataku na osmańskie umocnienia ${ }^{12}$. Ponieważ

${ }^{8}$ I. Hamilton, Gallipoli Diary, vol. 1, New York 1920, s. 1-3. Gen. Ian Hamilton zanim otrzymał nową nominację dowodził siłami mającymi zadanie bronić Wysp Brytyjskich przed ewentualną inwazją.

9 Szerzej patrz: G.H. Cassar, Kitchener's War. British Strategy From 1914 to 1916, Washington 2004.

${ }^{10}$ Po wybuchu wojny w Europie, brytyjskie dominia, chociaż nie były do tego zobowiązane, zaoferowały pomoc Metropolii. Istniejące przed wojną siły zbrojne poszczególnych dominiów przeznaczone były wyłącznie do obrony ich terytoriów, i były przy tym bardzo nieliczne. W związku z tym wojska ekspedycyjne zorganizowano od podstaw z ochotników, którzy zgłosili się do służby w Europie. Siły australijskie i nowozelandzkie, liczące ok. 30 tys. ludzi, wyruszyły w drogę do Europy 1 października 1915 roku. Jednak w trakcie rejsu zdecydowano, że lepszy punkt docelowy stanowić będzie Egipt. W tym czasie w Europie zbliżała się zima, i uznano, że klimat bliskiego wschodu lepiej będzie służył żołnierzom a antypodów. Ponadto oddziały te zostały dopiero co zorganizowane z niewyszkolonych ochotników, i wymagały ok. półrocznego szkolenia, by móc przystąpić do walki. Uznano, ze Egipt będzie stanowił najlepsze miejsce do tego zadania, a ponadto wojska te wzmocnią obronę tego kraju przed ewentualną inwazją sił Imperium Osmańskiego, które w tym czasie przystąpiło do wojny po stronie państw centralnych; szerzej na ten temat patrz: C.E.W. Bean, Official History of Australia in the War of 1914-1918. Vol. 1. The Story of ANZAC from the outbreak of war to the end of the first phase of the Gallipoli Campaign, May 4, 1915, Canberra 1941, s. 131-132.

11 Australijska 1. DP składała się z 1., 2. oraz 3. Brygady Piechoty, Nowozelandzka i Australijska Dywizja Piechoty (New Zealand \& Australian Infantry Division) obejmowała australijską 4. BP oraz Nowozelandzką Brygadę Piechoty, australijską 1. Lekką Brygadę Konną (Light Horse Brigade) oraz Nowozelandzką Brygadę Strzelców Konnych (New Zealand Mounted Riffle Brigade). Ponadto dwie kolejne australijskie brygady konne, 2. oraz 3., podlegały bezpośrednio gen. Birdwoodowi. Nie ma tutaj miejsca na dokładną charakterystykę sił ANZAC, została ona przedstawiona w moim osobnym artykule, do którego pozwolę sobie odesłać zainteresowanych. Tam także znajduje się charakterystyka uzbrojenia oraz organizacja brytyjskich dywizji: patrz: P. Korzeniowski, Charakterystyka alianckich sit lądowych bioracych udziat $w$ desancie na Pótwyspie Gallipoli 25 kwietnia 1915 roku [w:] O powinnościach żotnierskich, t. III, pod red. A. Drzewieckiego, Oświęcim 2016, s. 422-427.

12 3rd Australian Infantry Brigade War Diary, Headquarters, August 1914-April 1915, The National Archives (TNA), sygn. WO 95/4344. 
zakończył się on niepowodzeniem i konieczne stało się przeprowadzenie desantu, pozostałe siły ANZAC miały dołączyć do tej brygady, z wyjątkiem brygad konnych, które tymczasowo pozostały w Egipcie ${ }^{13}$.

Ponieważ oddziały gen. Birdwooda nie zakończyły jeszcze szkolenia, ich wartość bojowa była ograniczona. Marsz. Kitchener zdawał sobie sprawę, że przynajmniej w początkowej fazie lądowania, opór sił osmańskich może być duży, dlatego należało wzmocnić MEF przynajmniej jedną pełnowartościowa dywizją. W styczniu 1915 roku na Wyspach Brytyjskich z batalionów sprawdzonych z Indii i Dalekiego Wschodu zorganizowano 29. Dywizję Piechoty ${ }^{14}$. Początkowo miała trafić, podobnie jak pozostałe regularne dywizje, do Francji. Zdecydowano jednak, że „tymczasowo” zostanie ona „wypożyczona” gen. Hamiltonowi. Po przeprowadzeniu udanego desantu i szybkim złamaniu oporu oddziałów osmańskich, miała zostać wycofana z Półwyspu Gallipoli i skierowana na front zachodni ${ }^{15}$.

Ostatnim brytyjskim komponentem MEF była Królewska Dywizja Morska (Royal Naval Division), dowodzona przez gen. Archibalda Parisa. Została ona zorganizowana z inicjatywy ówczesnego Pierwszego Lorda Admiralicji, Winstona Churchilla, z nadwyżek mobilizacyjnych floty, i formalnie podlegała Admiralicji, nie Sekretariatowi Wojny. Składała się z brygady piechoty morskiej (Royal Marine Light Infantry Brigade) oraz dwóch tzw. brygad morskich (Naval Brigade ${ }^{16}$. Wbrew nazwie, nie był to pełnowartościowy związek taktyczny, gdyż oprócz wspomnianych trzech brygad piechoty, nie dysponowała ona, poza kompanią łączności, żadnymi pododdziałami wsparcia, w tym artylerią organiczną. W związku z tym możliwości jej aktywnego wykrzesywania w walkach były bardzo mocno ograniczone ${ }^{17}$.

W skład MEF weszły także oddziały francuskie. Zostały one zgrupowane w ramach tzw. Korpusu Ekspedycyjnego Orientu (Corps Expéditionnaire d'Orient - CEO), pod dowództwem gen. Alberta d'Amade. Składały się one z pojedynczej dywizji piechoty (1. DP CEO) gen. Josepha Masnou. Dywizja powstała na bazie 17. Dywizji Piechoty Kolonialnej (17 $7^{e}$ Division d'Infanterie Coloniale) i składała się z dwóch brygad, 1. Metropolitalnej Brygady Piechoty gen. Vandenberga oraz 2 . Kolonialnej Brygady Piechoty płk. Reufa ${ }^{18}$.

${ }^{13} \mathrm{~W}$ niniejszym tekście skupiam się jedynie na procesie rozbudowy sił alianckich, stąd pominę cały proces przygotowań do desantu jak i samą operację. Pierwsza $\mathrm{z}$ ww. kwestii została przeze mnie scharakteryzowana w następującej pozycji: P. Korzeniowski, Przygotowania do lądowania sit alianckich na Pótwyspie Gallipoli 25 kwietnia 1915 r. [w:] Człowiek i technika na polach bitew wojen światowych, pod red. A. Olejko, P. Korzeniowskiego, Rzeszów 2016, s. 212-225.

${ }_{14}$ Dywizja, początkowo dowodzona przez gen. Fredericka Shaw'a, w marcu została oddana gen. Aylmerowi Hunter-Westonowi. Składała się z 86. BP (gen. Steuart Hare), 87. BP (gen. William Marshall) oraz (88. BP (gen. Henry Napier); S. Gillonn, The Story of 29th Division. A Record of Gallant Deeds, London, Edinburgh, New York 1925, s. 254.

15 C.F. Aspinal-Oglander, Official History..., s. 87-91.

${ }^{16}$ Brygady tej dywizji posiadały analogiczną organizację jak brygady piechoty armii, i składały się z czterech batalionów, z których każdy liczył ok. tysiąca oficerów i żołnierzy.

${ }_{17}$ Szerzej na temat organizacji dywizji patrz: E.C. Coleman, Khaki Jack. The Royal Naval Division in The First World War, Stroud 2014, s. 9-51.

18 1. brygada składała się z francuskiego 175. Regimentu Piechoty oraz 1. Regiment Marszowy Afryki ( $I^{\text {er }}$ régiment de marche d'Afrique), złożonego z 2 batalionów żuawów oraz mieszanego batalionu legii cudzoziemskiej. Brygada kolonialna dysponowała 4. oraz 6. Mieszanym Regimentem Kolonialnym (Régiment Mixte Colonial). Dokładna organizacja dywizji i jej pododdziałów patrz: Historique du 175e régiment d'infanterie pendant la guerre 1914-1919, Nancy-Paris-Stras- 
MEF liczyły ok. 80 tys. ludzi, na które składało się ok. 30 tys. żołnierzy ANZAC, ok. 20 tys. z 29. DP, ok. 10 tys. RND ${ }^{19}$ oraz niecałe 20 tys. sił francuskich. Wskazać należy, że prezentowały one nie tylko konglomerat wojsk $\mathrm{z}$ różnych miejsc globu, ale także ocena ich wartości bojowej wypada bardzo różnie. Najsilniejszym komponentem MEF była 29. DP, która choć zorganizowana niedawno, składała się z żołnierzy zawodowych, mających za sobą już kilka lat służby, w dodatku w obszarach, na których dochodziło często do starć granicznych. Byli wiec oni już „ostrzelani” i udział w walce nie był dla nich nowością, choć oczywiście były to starcia o znacznie mniejszej intensywności. Siły ANZAC nie zakończyły jeszcze szkolenia, a także miały braki w zaopatrzeniu. Żołnierze, będący ochotnikami, charakteryzowali się bardzo dużym entuzjazmem, ale dotychczas nie uczestniczyli w walce, i ich chrzest bojowy stanowił wyjątkowe wyzwanie nawet dla doświadczonych oddziałów, zarówno pod kątem fizycznym, jak i psychicznym. Najsłabiej wypada ocena RND, która nawet nie była pełnowartościowym związkiem taktycznym, a jedynie „czystą” piechotą, wobec czego możliwości jej wykorzystania były bardzo małe i ograniczały się jedynie do realizacji zadań pomocniczych oraz wsparcia pozostałych sił pojedynczymi batalionami.

Wojska francuskie, choć zorganizowane w nieco improwizowany sposób, były dobrze wyszkolone, a ponadto dysponowały silnym wsparciem artylerii, a co chyba jeszcze ważniejsze, znacznymi zapasami amunicji do niej. Ponadto kontyngent francuski był znacznie lepiej przygotowany do walki pod względem zaopatrzenia w materiały wojenne, a także dowództwo CEO znacznie sprawniej radziło sobie z wyzwaniami logistycznymi, jakie stanęły przed alianckimi wojskami w czasie kampanii.

Braki w wyszkoleniu i przygotowaniu do działań bojowych dały o sobie znać w dniu lądowania. Desant, przeprowadzony w dniu 25 kwietnia zakończył się jedynie częściowym sukcesem. Co prawda udało się aliantom opanować plaże w dwóch sektorach, ale nie zdołano opanować kluczowych punktów ani tym bardziej przełamać obrony wojsk osmańskich $^{20}$. Podejmowane w ciągu kolejnych kilku dni próby rozwinięcia częściowego powodzenia zakończyły się niepowodzeniem, zdołano jedynie zyskać nieco terenu na południu półwyspu, ale w dalszym ciągu nie udało się opanować kluczowych pozycji ${ }^{21}$. W bardzo intensywnych walkach wojska MEF poniosły ogromne straty i poszczególne związki taktyczne utraciły możliwość kontynuowania działań zaczepnych. Aby móc je wznowić konieczne było wzmocnienie wojsk alianckich dodatkowymi oddziałami, tym bardziej że także przeciwnik systematycznie otrzymywał wzmocnienia ${ }^{22}$.

burg b.d.w., s. 2-3; Historique du ler regiment de marche d'Afrique, Bizerte, b. d.w., s. 7-9; Historique du 56e régiment d'infanterie coloniale. Présentement 6e régiment mixte d'infanterie coloniale, Strasbourg 1920, s. 3; Les Armées Françaises dans la Grande Guerre, Tomme VIII, Premiere Volume, Paris 1923, s. 49-52.

$19 \mathrm{~W}$ momencie lądowania w rejonie Dardaneli znajdowało się 9 z 12 batalionów dywizji.

20 29. DP zdołała zająć plaże na południu Półwyspu Gallipoli, ponosząc przy tym jednak ogromne straty. Na północy, na zachodnim brzegu półwyspu, siły ANZAC także zdołały zająć przyczółek, ale próby opanowania dominujących grzbietów zakończyły się niepowodzeniem. Kontrataki osmańskich rezerw pod dowództwem płk. Mustafy Kemala zepchnęły żołnierzy z Australii i Nowej Zelandii niemal na sam brzeg, pomimo, że atakujący w tym miejscu posiadali kilkukrotną przewagę nad obrońcami.

21 Report on Landing of 29th Division in the Neighbourhood of Cape Helles, 29th Division War Diary, General Headquarters, April 1915, TNA, sygn. WO 95/4304.

${ }^{22}$ E.J. Erickson, Gallipoli. Command Under Fire, Oxford 2015, s. 143-144. 


\section{SYSTEMATYCZNE ZWIĘKSZANIE LICZEBNOŚCI MEF W LECIE 1915 ROKU (MAJ-LIPIEC)}

Wzmocnienie MEF dodatkowymi oddziałami w krótkim czasie nie było możliwe. W rzeczywistości jedynym źródłem dodatkowych oddziałów w tym czasie mógł być Egipt $^{23}$. Już 27 kwietnia hinduska 29. Brygada Piechoty gen. Herberta Cox'a rozpoczęła załadunek w Port Saidzie ${ }^{24}$. Brygada, na czterech transportowcach, Japenaese Princess, Unfuli, Ajax oraz Ismaila dotarła 30 kwietnia w rejon Przylądka Helles, a następnego dnia rozpoczęto jej rozładunek, który potrwał do 4 maja ${ }^{25}$.

Na początku maja załadunek w Aleksandrii rozpoczęła brytyjska 42. Dywizja Piechoty (gen. William Douglas), należąca do Sił Terytorialnych ${ }^{26}$. Jej pierwsze elementy, 125. BP, dotarła na Półwysep Gallipoli 5 maja, ale jej rozładunek przeciągał się. Ostatnie pododdziały piechoty znalazły się na brzegu dopiero 9 maja, a pozostałe elementy w ciągu następnych dni. Stąd dywizja mogła wziąc udział w walkach dopiero w połowie miesiąca $^{27}$.

Nie tylko Brytyjczycy zdecydowali się wzmocnić swoje siły. Także w Paryżu uznano, że w zaistniałej sytuacji także francuski kontyngent należało wzmocnić. Już pod koniec kwietnia 1915 roku, w oparciu dowództwo 156. Dywizji Piechoty utworzono 2. Dywizję Piechoty CEO ( $2^{\mathrm{e}}$ division d'infanterie du corps expéditionnaire d'Orient), pod dowództwem gen. Maurece'a Bailloud. Miała ona analogiczną strukturę jak jej siostrzana dywizja, i składała się z 3. Metropolitalnej Brygady Piechoty (gen. Dauvé) oraz 4. Kolo-

${ }^{23}$ Początkowo dowodzący brytyjskimi siłami na tym obszarze, gen. John Maxwell, bardzo niechętnie współpracował z gen. Hamiltonem, obawiając się, że działania w rejonie Dardaneli zepchną na margines jego obszar odpowiedzialności. Dlatego negatywnie ustosunkował się do prośby dowódcy MEF, by „wymienić” brygady konne ANZAC na jedną z hinduskich brygad piechoty. Widząc trudności alianckich oddziałów na półwyspie obawiał się, że ewentualna klęska mogłaby doprowadzić do zamieszek, a nawet buntu nieprzychylnych Brytyjczykom Egipcjan. Stąd diametralnie zmienił swoje podejście i udostępnił gen. Hamiltonowi wszelkie dostępne zasoby i siły. G.H. Cassar, Kitchener's War. British Strategy From 1914 to 1916, Washington 2004, s. 45-51.

${ }^{24}$ Brygada w tym czasie składała się z 4 batalionów: 14. Sikhów (dokładniej 14th King George's Own Ferozepore Sikhs), 69. oraz 89. Punjabis oraz 1./6. Gurkha Rifles (6th Queen Elizabeth's Own Gurkha Rifles). Ponieważ dwa bataliony z Pendżabu w dużej części składały się z muzułmanów, początkowo były wykorzystywane jedynei do prac na plażach, wkrótce zaś zostały odesłane do Egiptu, a ich miejsce zajęły dwa bataliony Gurkhów, 1./5. oraz 2./10. Gurkha Rifles; Order of Battle of the Mediterranean Expeditionary Force, April 1915, TNA, sygn. WO 95/5473.

25 29th Indian Infantry Brigade War Diary, April-May 1915, TNA, sygn. WO 95/4272.

${ }^{26}$ Ponieważ dywizja należała do Sił Terytorialnych a nie Armii regularnej 9Regular Army), początkowo zamiast numeru nosiła nazwę własną pochodzącą od miejsca stacjonowania, mianowicie East Lancashire. Numer „42” otrzymała dopiero w maju 1915 roku, zachowując jednocześnie także wspomnianą nazwę własną.

Składała się z 3 brygad: 125. BP (Lancashire Fusilliers, dowódca gen. H.C. Frith); 126. BP (East Lancashire, dowódca gen. D.G. Prendergast) oraz 127. BP (Manchester, dowódca gen. N. Lee). Order of Battle of Mediterranean Expeditionary Force, June 1915, TNA, sygn. WO 95/5473; obsada personalna patrz: F.P. Gibbon, The 42nd (East Lancashire) Division 1914-1818, Eastbourne 1920, s. 17-18.

27 42nd Infantry Division War Diary, General Headquarters, May 1915, TNA, sygn. WO 95/4313. 
nialnej Brygady Piechoty (gen. Simonin) ${ }^{28}$. Pierwsze elementy dywizji zaczęły lądować w rejonie Przylądka Helles 6 maja, zaś jej całkowity rozładunek zakończył się ok. 20 maja $^{29}$.

Przedłużający się transport, a zwłaszcza rozładunek nowych oddziałów sprawił, że gen. Hamilton mógł odłożyć wznowienie działań zaczepnych do połowy maja 1915 roku, albo podjąć kolejną próbę przełamania jeszcze przed koncentracją wszystkich dodatkowych sił. Zdecydował się na to drugie rozwiązanie, wzmacniając dotychczasowe oddziały jedynie hinduską 29. BP oraz 125. BP z 42. DP. Ponadto na południe Półwyspu Gallipoli z sektora ANZAC przerzucono dwie najmniej wyczerpane brygady piechoty, australijska 2. BP oraz Nowozelandzką BP. W dniach 6-8 maja miała miejsce tzw. Druga Bitwa o Kritkię, która ponownie zakończyła się niepowodzeniem sił alianckich, głownie ze względu na zbyt słabe wsparcie artyleryjskie i kiepską koordynację działań alianckich oddziałów ${ }^{30}$. Straty sił alianckich szacować można na ok. 6,5 tys. żołnierzy z ok. 20 tys. uczestniczących w walkach. W rezultacie oddziały MEF w większości utraciły znaczną cześć zdolności bojowej i musiały przejść do defensywy w oczekiwaniu na dalsze wzmacniania ${ }^{31}$.

W czasie, gdy trwała reorganizacja alianckich oddziałów trwał proces ich uzupełniania i wzmacniania. Chwilowo nie było mowy, aby MEF w najbliższym czasie został wzmocniony kolejnymi większymi związkami taktycznymi. Stąd skupiono się na odbudowie stanów oddziałów, które znajdowały się na Półwyspie Gallipoli. 10 maja ANZAC otrzymał ok. 1250 ludzi, którymi uzupełniono najbardziej osłabione bataliony. Ponadto 11 maja rozpoczął się rozładunek pierwszych elementów czterech brygad kawalerii, które przed rozpoczęciem operacji pozostawiono w Egipcie. Proces ich rozładunku zakończono w ostatniej dekadzie maja. Oddziały te pozostawiły konie w Egipcie i na Półwyspie Gallipoli walczyły spieszne $^{32}$. Pomiędzy 14 a 18 maja dotarły także pierwsze większe uzupełnienia dla 29. DP

${ }^{28}$ Pierwszą brygadę tworzyły 176. Regiment Piechoty oraz 2. Regiment marszowy Afryki, drugą z brygad natomiast 7. oraz 8. Mieszany Regiment Kolonialny; Les Armées Françaises dans la Grande Guerre, Tomme X, Deuxiéme Volume, Paris 1924, s. 859-861.

${ }^{29}$ Rapport sur les opérations du Corps expéditionnaire d'Orient du 15 Mai au 3 Juin 1915, Corps Expeditionnaire d'Orient, 3e Bureau - Opérations, Service Historique de la Défence (SHD), sygn. GR 20 N 28/6.

${ }^{30}$ Szczególnie dla Brytyjczyków kwestia artylerii i amunicji artyleryjskiej stanowiła ogromny problem, nierozwiązany do końca całej kampanii. Nie tylko dysponowali oni bardzo małą liczbą dział, $\mathrm{w}$ stosunku do dywizji na froncie zachodnim, to w dodatku zaopatrzenie w amunicję artyleryjską było zdecydowanie niewystarczające, gdyż dla War Office priorytetem stanowiło zaopatrzenia wojsk we Francji. Stąd na Półwysep Gallipoli wysyłano tylko tyle zapasów, ile mówiąc kolokwialnie ,zostało" po zaopatrzeniu wojsk na froncie zachodnim. Co więcej, otrzymywano niemal wyłącznie szrapnele, zamiast tak potrzebnej amunicji odłamkowo-burzącej, niezbędnej do prowadzenia skutecznych walk $w$ trudnym terenie. Powyższe problemy sprawiły, że w drugiej połowie maja przyjęto, że w sytuacji, kiedy nie prowadzono większych działań bojowych dzienne zużycie amunicji artyleryjskiej na działo mogło wynieść jedynie dwa pociski. Jedynie w przypadku armat górskich limit ten wyniósł cztery sztuki. Zob. G.S. 39-8, Mediterranean Expeditionary Force War Diary, General Headquarters, Operations Section, May 1915, TNA, sygn. WO 95/4264.

${ }^{31}$ C.F. Aspinal-Oglander, Official History of The Great War. Military Operations. Gallipoli. Vol. 2. May 1915 to the Evacuation, London 1931, s. 4-8.

32 Była to Nowozelandzka Brygada Strzelców Konnych (New Zealand Mounted Rifles Brigade) oraz australijska 1. Lekka Brygada Konna (Light Horse Brigade). Obie brygady włączono formalnie do Nowozelandzkiej i Australijskiej Dywizji Piechoty. Pozostałe dwie brygady, australijskie 2. oraz 
(ok. 500 ludzi), a w ostatniej dekadzie maja na półwyspie znalazły się także trzy brakujące bataliony RND ${ }^{33}$.

Uzupełnienia i wzmocnienia, które dotarły na Półwysep Gallipoli w maju 1915 roku pozwoliły jedynie na odbudowę, i to nie w pełni, potencjału poszczególnych alianckich związków taktycznych, bardzo osłabionych w dotychczasowych walkach. 10 maja 1915 roku gen. Hamilton w depeszy do marsz. Kitchenera wskazywał, że brytyjskie siły od początku operacji straciły ponad 15 tys. ludzi, francuskie zaś ponad 12 tys. W jego opinii, wznowienie działań zaczepnych, które dawały szanse na rozstrzygniecie kampanii na korzyść Aliantów, były możliwe tylko po wzmocnieniu MEF co najmniej dwoma dodatkowymi dywizjami. Do tego czasu jego siły były w stanie prowadzić jedynie lokalne operacje, o znaczeniu taktycznym ${ }^{34}$.

Co prawda już 8 maja w War Office zdecydowano, aby wzmocnić MEF kolejną dywizją terytorialną. Jednakże w połowie maja w Wielkiej Brytanii wybuchł tzw. kryzys amunicyjny, który spowodował bardzo duże przetasowania w liberalnym rządzie Herberta Asquitha, i włączenie do niego polityków partii konserwatywnej. Zamieszanie polityczne spowodowało, że przez najbliższe kilka tygodni nie podejmowanie żadnych strategicznych decyzji związanych z prowadzeniem wojny. W rezultacie gen. Hamilton nie otrzymał odpowiedzi, czy otrzyma dodatkowe oddziały o które prosił, i czy dalej ma prowadzić działania zaczepne, czy przejść do defensywy ${ }^{35}$.

Tymczasem pod koniec maja w rejon Dardaneli dotarła wspominana dywizja terytorialna, mianowicie szkocka 52. Dywizja Piechoty ${ }^{36}$. Rozładunek dywizji na półwyspie rozpoczął się na początku czerwca, ale trwał dość długo, gdyż ostatnie elementy dywizji znalazły się na półwyspie dopiero w ostatniej dekadzie tego miesiąca ${ }^{37}$. Co więcej, sama dywizja została wysłana w rejon operacji mocno osłabiona, gdyż bez dwóch z czterech brygad artylerii ${ }^{38}$.

W maju miała miejsce także reorganizacja alianckiego systemu dowodzenia. Dotychczas był on bardzo mocno improwizowany i nastręczał wiele trudności. Mianowicie w północnym sektorze, w rejonie Gaba Tepe, znajdowały się oddziały australijskie i nowozelandzkie, zgrupowane w ramach ANZAC (2 dywizje piechoty). Natomiast na południu,

3., po przybyciu na półwysep podporządkowano dowództwu ANZAC. Australian \& New Zealand Army Corps War Diary, General Headquarters, May-June 1915, TNA, sygn. WO 95/4280.

3323 maja na półwysep dotarł batalion „Collingwood”, następnego dnia „Hawke”, zaś 28 maja „Benbow”. Mediterranean Expeditionary Force War Diary, „Q” Branch, May 1915, TNA, sygn. WO 95/4266.

${ }^{34}$ From General Sir Ian Hamilton to Earl Kitchener, 10th May 1915, Dardanelles, Mediterranean Expeditionary Force War Diary, General Headquarters, Telegrams Regardings The Military Operations, TNA, sygn. WO 95/4264.

35 C.F. Aspinal-Oglander, Official History..., Vol. 2, s. 28-34.

${ }^{36}$ Mediterranean Expeditionary Force War Diary, General Headquarters, May 1915, TNA, sygn. WO 95/4264. Podobnie jak przybyła wcześniej 42. DP, także ona posiadała początkowo jedynie nazwę własną, „Lowlands”. Składała się z trzech brygad piechoty: 155. (South Scotish), 156. (Scotish Rifles) oraz 157. (Highland Light Infantry). Dowódcą dywizji był gen. Grenville Egerton. R.R. Thompson, The Fifty-Second Lowland Division 1914-1918, Glasgow 1923, s. 3-5.

${ }^{37}$ Mediterranean Expeditionary Force War Diary, ,Q” Branch, May 1915, TNA, sygn. WO 95/4266.

${ }^{38}$ From Earl Kitchener to General Sir Ian Hamilton, 18th May 1915, Dardanelles. Mediterranean Expeditionary Force War Diary, General Headquarters, Telegrams Regardings The Military Operations, TNA, sygn. WO 95/4264. 
kontyngent francuski, złożony z dwóch dywizji piechoty, podlegał dowództwu CEO. Z kolei brytyjskie dywizje w rejonie Przylądka Helles nie podporządkowano osobnemu dowództwu szczebla operacyjnego, ale formalnie podlegały gen. Hamiltonowi, dowódcy $\mathrm{MEF}^{39}$. W praktyce jednak rolę koordynatora ich działań pełnił dowódca 29. DP, gen. Hunter-Weston. Aby uporządkować strukturę dowodzenia, 24 maja 1915 roku oficjalnie aktywowano VIII Korpus Armijny, któremu podporządkowano brytyjskie siły na południu półwyspu. Na jego dowódcę wyznaczono gen. Hunter-Westona, którego na dotychczasowym stanowisku zastąpił gen. Henry de Beauvoir de Lisle, który przybył na półwysep wieczorem 4 czerwca $^{40}$.

Pod koniec maja zakończono proces odbudowy zdolności bojowej przez alianckie oddziały. Pozwoliło to na ponowne przejście przez aliantów do działań zaczepnych. Tym niemniej, ze względu na fakt, że również siły osmańskie systematycznie zwiększały swój potencjał, a także rozbudowywały stanowiska obronne, nie było mowy o przeprowadzeniu rozstrzygającej ofensywy, z czego gen. Hamilton doskonale zdawał sobie sprawę. Stąd w sztabie MEF zdecydowano, że celem najbliższej operacji miało być jedynie przesunięcie linii frontu tak, by zabezpieczyć zaplecze oddziałów i zdobyć teren dla spodziewanych kolejnych oddziałów ${ }^{41}$.

Ofensywa, która przeszła do historii jako Trzecia bitwa o Krithię, rozpoczęła się 4 czerwca. Tego dnia atakująca w centrum 42. DP zdołała włamać się w pozycje przeciwnika na ok. kilometr, ale na skrzydłach wojska alianckie nie poczyniły niemal żadnych postępów. W ciągu dwóch kolejnych dni siły osmańskie przeprowadziły szereg kontrataków, odzyskując cześć terenu. W walkach między 4 a 6 czerwca wojska alianckie straciły ok. 10 tys. ludzi, z 20 tys. bezpośrednio zaangażowanych w walki (30 tys. w sumie), zdobywając jedynie kilkaset metrów terenu, i to tylko w centrum ugrupowania ${ }^{42}$. Stało się jasne, że w istniejącej sytuacji, dostępne siły były zbyt słabe, by móc rozstrzygnąć kompanię na korzyść aliantów.

\section{WZMOCNIENIE MEF PRZED I W TRAKCIE OFENSYWY SIERPNIOWEJ}

Niepowodzenie w Trzeciej bitwie o Krithię postawiło przed brytyjskim kierownictwem polityczno-wojskowym dylemat co do dalszych losów kampanii. W zasadzie możliwe były trzy decyzje w tym zakresie: wzmocnienie MEF bardzo dużymi siłami, aby móc przeprowadzić rozstrzygająca ofensywę, jedynie uzupełnienie oddziałów alianckich do pełnych stanów i przejście do działań defensywnych, zadowalając się absorbowaniem wojsk osmańskich lub zakończyć całą operację i wycofać wojska z Półwyspu Gallipoli, kierując je na inny teatr wojenny.

${ }^{39} \mathrm{~W}$ tym czasie w dowództwu ANZAC podlegały dwie dywizje piechoty, australijska 1. DP oraz Nowozelandzka i Australijska DP. Ponadto w tym rejonie znajdowały się cztery brygady kawalerii, z których dwie włączono do ostatniej z wymienionych dywizji. Kontyngent francuski obejmował dwie dywizje, 1. oraz 2. DP CEO. Wojska brytyjskie składały się w tym czasie z 29. DP, RND, 42. DP oraz hinduskiej 29. BP. Jak zaznaczyłem wyżej, w czerwcu na półwyspie rozładowywała się powoli także 52. DP. Order of Battle of the Mediterranean Expeditionary Force, June 1915, TNA, sygn. WO 95/5473.

${ }^{40} \mathrm{Na}$ froncie zachodnim dowodził 2. Brygadą Kawalerii, następnie zaś 1. Dywizją Kawalerii.

${ }^{41}$ Instructions to General Officers Commanding Corps, 2nd June 1915, Mediterranean Expeditionary Force War Diary, General Headquarters, May 1915, TNA, sygn. WO 95/4264.

${ }^{42}$ C.F. Aspinal-Oglander, Official History..., Vol. 2, s. 46-55. 
Kwestie te stały się tematem obrad Komitetu dardanelskiego 7 czerwca 1915 roku $^{43}$. W tym czasie kończyła się organizacja i szkolenie pierwszych sześciu dywizji tzw. Nowej Armii, którą rozpoczęto tworzyć w sierpniu 1914 roku ${ }^{44}$. Planowano, że wszystkie dostępne siły kierowane powinny być na front zachodni. Jednakże wspólne, francusko-brytyjskie ustalenia zakładały, że wznowienie działań zaczepnych we Francji nastąpić miało najwcześniej w połowie września 1915 roku. Stąd w Londynie uznano, że dało to czas na wysłanie części dostępnych sił w rejon Dardaneli, aby wreszcie rozstrzygnąć całą kampanię. Szybkie zwycięstwo powinno dać wspomniane na początku niniejszego opracowania korzyści strategiczne oraz zwolni większość zaangażowanych na tym teatrze wojennym sił do działań na froncie zachodnim ${ }^{45}$.

Stąd zdecydowano, że gen. Hamiltonowi zostaną wysłanie nie tylko dwie dywizje, o które prosił, ale znacznie większe siły. Miało to zapewnić powodzenie bez względu na ewentualne trudności czy nieprzewidziane wydarzenia na froncie. Na wspomnianym posiedzeniu zdecydowano, że w rejon Dardaneli wysłane zostaną aż trzy dywizje Nowej Armii (10., 11. oraz 13. DP). Niestety, problem, jaki pojawił się przed War Office i Admiralicją stanowił transport tych sił w rejon Dardaneli. Już przerzut 52. DP i jej rozładunek pokazał, że przedsięwzięcie to stanowiło logistyczne wyzwanie. Analiza możliwości transportowych wskazywała, że o ile pierwsze z wymienionych dywizji mogła znaleźć się w rejonie Dardaneli do 1 lipca, o tyle druga dopiero 28 lipca, a trzecia nie wcześniej niż 20 sierpnia. Stąd na spotkaniu Komitetu Dardanelskiego uznano, że aby przyśpieszyć transport żołnierzy Admiralicja powinna wykorzystać wielkie liniowce, dzięki czemu ostatnia z obiecanych dywizji mogła dotrzeć na miejsce już 24 lipca, a wiec prawie miesiąc wcześniej niż pierwotnie planowano ${ }^{46}$.

${ }^{43}$ Po reorganizacji rządu H. Asquitha, Rada Wojenna została przemianowana na Komitet Dardanelski (Dardanelles Comitee).

${ }^{44}$ Po objęciu funkcji Sekretarza ds. Wojny marsz. Kitchener zdecydował się niemal natychmiast przystąpić do rozbudowy Armii Regularnej w oparciu o ochotników, którzy zgłosiliby się do trzyletniej służby wojskowej. Planowano utworzyć 30 nowych dywizji piechoty podzielonych na cztery serie, po 6 dywizji. Choć na słynny apel odpowiedziały setki tysięcy ochotników, to problemem pozostawało uzbrojenie i wyekwipowanie tak dużej liczby żołnierzy, a także obsadzenie stanowisk oficerskich. Pomimo tych trudności w połowie 1915 roku pierwsze sześć dywizji, o numerach 9-14 było w praktyce gotowych do wysłania na front. Szerzej patrz: P. Simkins, Kitchener's Army. The Rising of the New Armies 1914-1916, Barnsley 2007, s. 66-75; M. Middlebrook, Your country needs you. From six to sixty-five divisions, Barnsley 2000, s. 45-18.

${ }^{45}$ Secretary's Notes of A Meeting of The Dardanelles Comitee Held At a Hause of Commons, June 7, 1915, TNA, War Council, sygn. CAB 22/2/1, s. 5. 10. DP (Irlandzka), dowodzona była przez gen. Briana Mahona i składała się z 29., 30. oraz 31. BP, 11. DP, pod dowództwem gen. Fredericka Hammersley'a, obejmowała 32., 33. oraz 34. BP, zaś 13. DP, gen. Fredericka Shawa (pierwszego dowódcy 29. DP) dysponowała 39., 39. oraz 40. BP. Order of Battle of the Mediterranean Expeditionary Force, August 1915, TNA, sygn. WO 95/5473.

${ }^{46}$ Były to Aquitania, Mauretania oraz Olympic. Każda z tych jednostek mogła zabrać 9-10 tys. ludzi. Pierwotnie obawiano się, że wykorzystywanie dużych liniowców mogło stwarzać ogromne ryzyko związane $\mathrm{z}$ aktywnością niemieckich okrętów podwodnych. Zatopienie nawet jednego z tych statków mogło spowodować utratę połowy dywizji piechoty. Uznano jednak, że możliwość przyśpieszenia operacji o miesiąc warte jest podjęcia tego ryzyka. Secretary's Notes of A Meeting of The Dardanelles Comitee Held At Downing Street 10, June 17, 1915, TNA, War Council, sygn. CAB 22/2/1, s. 12-15. 
Powyższe rozwiązanie nie tylko pozwoliło na szybszy transport obiecanych dywizji, ale także stworzyło możliwość wysłania nawet większych sił. Stąd 21 czerwca marsz. Kitchener zaoferował wysłanie kolejnej terytorialnej dywizji piechoty, na co gen. Hamilton niezwłocznie przystał ${ }^{47}$. Wybór padł na 53. DP, wchodzącą w tym czasie w skład tzw. Home Force $^{48}$. Były to siły przeznaczone do obrony Wysp Brytyjskich przed ewentualną inwazją. W połowie 1915 roku takie ryzyko było niewielkie, a ponadto kończyło się szkolenie kolejnych dywizji Nowej Armii, które w razie konieczności mogły przejąć tę rolę, pozwalając na wysłanie także innych jednostek terytorialnych na front. Stąd, gdy 5 lipca Departament Transportu Admiralicji (Admiralty Transport Department) poinformował, że w sytuacji, gdyby nie było konieczne trzymanie się ram organizacyjnych poszczególnych oddziałów w trakcie transportu, możliwe byłoby przetransportowanie w rejon Dardaneli jeszcze jednej dywizji piechoty ${ }^{49}$.

W związku z tym marsz. Kitchener zdecydował, że jeszcze jedna, 54. DP, zostanie wysłana tym razem do Egiptu ${ }^{50}$. Ponieważ dotychczasowa praktyka pokazywała, że oddziały terytorialne miały ogromny problem z pozyskiwaniem uzupełnień, zdecydowano, że ta dywizja wyruszyć miała bez artylerii, i stanowić źródło uzupełnień strat dla pozostałych dywizji terytorialnych. Tylko w razie wyjątkowej konieczności, zakładano możliwość skierowania jej do walki ${ }^{51}$. Oprócz 5 nowych dywizji zdecydowano także na znaczne zwiększenie ilości amunicji artyleryjskiej wysyłanej w rejon Dardaneli, a także wysłano dwie baterie haubic 4,5 cala. Z drugiej strony pamiętać należy, że dwie dywizje terytorialne wysłano bez ich artylerii organicznej.

Wymienione powyżej dodatkowe dywizje zostały zgrupowane w ramach IX Korpusu Armijnego, na czele którego stanął gen. Frederick Stopford ${ }^{52}$. Miały one zakończyć koncentrację w rejonie Dardaneli na początku sierpnia. Do tej pory wojska alianckie próbowały uzyskać przełamanie osmańskich pozycji na południu półwyspu, gdyż obszar zajmowany przez ANZAC był wyjątkowo niesprzyjający dla działań zaczepnych. Wojska nieprzyja-

${ }^{47}$ Oddziały mające zabezpieczać Wyspy Brytyjskie przed ewentualną inwazją niemiecką. Składały się głównie z Sił Terytorialnych oraz dywizji nowych armii przechodzących aktualnie szkolenie.

48 53. DP, pod dowództwem gen. Johna Lidley'a, formowana była w Walii i oprócz numeru nosiła nazwę „Welsh”. Składała się z 158., 159. oraz 160. BP; D. Ward, History of The 53rd (Welsh) Division (T.F.) 1914-1918, Cardiff 1927, s. 10-11. Dywizja została wysłana w rejon Dardaneli bez swojej artylerii organizcznej.

49 Mówiąc wprost, oficerowie Admiralicji zasugerowali, że są w stanie „upchać” ekwiwalent dywizji na różnych transportowcach, wypływających na Morze Śródziemne, ale nie byli w stanie z wyprzedzeniem powiedzieć, kiedy, gdzie i jak poszczególne elementy dotrą na miejsce.

50 Dywizja, pod dowództwem gen. Francis'a Inglefielda, formowana we Wschodniej Anglii (East Anglian). Jej trzy brygady nosiły numery 161., 162. oraz 163. Order of Battle of the Mediterranean Expeditionary Force, August 1915, TNA, sygn. WO 95/5473.

${ }^{51}$ Secretary's Notes of A Meeting of The Dardanelles Comitee Held At Downing Street 10, July 5, 1915, TNA, War Council, sygn. CAB 22/2/1, s. 23-26

${ }^{52}$ Na początku wojny był komendantem Tower of London, co było zaszczytną, ale wyłącznie prestiżową funkcją. W swojej karierze nigdy nie dowodził oddziałami w polu, a mianowanie go na dowódcę korpusu wynikało z faktu, że jako jeden z nielicznych generałów przewyższał starszeństwem wszystkich dowódców dywizji. Apele gen. Hamiltona, aby na dowódcę korpusu oraz dowódców dywizji mianować doświadczonych oficerów, mających za sobą walki we Francji, spotkały się z odmową marsz. Kitchenera. J. Laffin, The Agony of Gallipoli, Oxford 2005, s. $153-154$. 
ciela zajmowały wszystkie dominujące pozycje, a ponadto w tym rejonie zwyczajnie nie było miejsca dla dodatkowych sif $^{53}$.

Tymczasem w ciągu ostatnich miesięcy także na południu półwyspu wojska osmańskie znacznie rozbudowały inżynieryjnie swoje stanowiska obronne. Ze względu na szczupłość artylerii, perspektywa ich przełamania, nawet mając do dyspozycji wymienione wyżej dodatkowe dywizje, była wątpliwa. Stąd zdecydowano się na śmiałe rozwiązanie. Mianowicie wojska alianckie na południu półwyspu, jak też siły ANZAC, miały równocześnie rozpocząć operacje zaczepne, angażując osmańskie siły w obu sektorach ${ }^{54}$. W tym samym czasie IX KA miał przeprowadzić operację desantową na północ od rejonu AZNAC, w Zatoce Suvla, i wyjść na tyłu osmańskiego zgrupowania w rejonie wiosek Küçük i Büyük Anafarta $^{55}$.

Wielka aliancka ofensywa rozpoczęła się 6 sierpnia. Na południu półwyspu wojska brytyjskie zaatakowały pozycje osmańskie w rejonie Krithia Vineyard, zaś na północy australijska 1. DP zaatakowała w rejonie Lone Pine, absorbując wojska przeciwnika. W tym samym czasie w Zatoce Suvla wylądowały pierwsze oddziały IX KA, nie napotykając na opór ze strony przeciwnika. Zgodnie z przyjętym planem operacji, powinny one natychmiast obsadzić okoliczne wzgórza i jak najszybciej uderzyć na tyły wojska osmańskich w tym rejonie, zanim te zostaną wzmocnione odwodami. Zamiast tego jednak gen. Stopford działał bardzo opieszale, i skupił się na rozładunku kolejnych oddziałów, nie zabezpieczając nawet dostatecznie samej zatoki. Kolejne ponaglenia ze strony gen. Hamiltona nie przynosiły zmiany jego postawy, mimo że dwie brytyjskie dywizje (10. oraz 11. DP) miały przed sobą jedynie kilka osmańskich batalionów piechoty ${ }^{56}$.

8 sierpnia na brzeg zaczęły schodzić bataliony 53. DP, a dwa dni później także 54. DP, mimo iż ta początkowo nie miała uczestniczyć w walkach, ale stanowić źródło uzupełnień. Niekompetencja dowódcy IX KA była porażająca, jego oddziały bardzo nieumiejętnie dowodzone, ponosiły ogromne straty, raz za razem odrzucane przez przeciwnika, który zaczynał otrzymywać posiłki. Jednakże dopiero 15 sierpnia gen. Hamilton zdecydował się usunąć go ze stanowiska, a funkcję dowódcy korpusu powierzyć gen. de Lisle. Spowodowało to niezadowolenie kilku dowódców dywizji, którzy złożyli dymisje ${ }^{57}$.

${ }^{53}$ Patrz m.in. L.A. Carlyon, Gallipoli, London-New York-Toronto-Sydney-Auckland 2001, s. $338-342$.

${ }^{54}$ Ponadto w czerwcu i lipcu zarówno wojska brytyjskie, jak i francuskie przeprowadziły kilka lokalnych ataków, których celem było poprawienie zajmowanych pozycji. Działania te przyniosły pewne korzyści terenowe, ponadto miały sprawiać wrażenie, że główny wysiłek sił alianckich w dalszym ciągu skupiony będzie na południu półwyspu. Szerzej patrz: H. Broadbent, Gallipoli. The Fatal Shore, Camberwell 2009, s. 184-208; C.F. Aspinal-Oglander, Official History..., Vol. 2, s. 79-112.

55 Force order No. 25, 2nd August 1915, Mediterranean Expeditionary Force War Diary. General Headquarters, August 1915, TNA, sygn. WO 95/4264.

56 13. DP została podporządkowana dowództwu ANZAC.

${ }^{57}$ Dowódcą IX KA został wyznaczony gen. Julian Byng, który w tym czasie znajdował się we Francji. Do czasu jego przybycia tymczasowe dowództwo korpusu powierzono dotychczasowemu dowódcy 29. DP. Wraz z gen. Stopfordem gen. Hamilton odwołał gen. Fredericka Hammerslaya, dowódcę 11. DP, zdecydował się pozostawić na stanowisku gen. Bryana Mahona, dowódcę 10. DP. Ten jednak, gdy dowiedział się, że jego zwierzchnikiem ma być gen. de Lisle, złożył rezygnację, nie godząc się na wykonywanie rozkazów generała, którego przewyższał starszeństwem. Gen. Mahon nie czekał na odpowiedź ze sztabu MEF na złożoną rezygnację i opuścił swoje 
W rezultacie ogromna szansa, jaką posiadali Brytyjczycy, na rozbicie osmańskich sił w tym rejonie, została zmarnowana. Gen. Hamilton liczył jeszcze, że uda się wznowić działania zaczepne i przynajmniej zająć najważniejsze punkty terenowe i zabezpieczyć rejon lądowania. Pozwoliłoby to przynajmniej stworzyć solidną podstawę do dalszych działań. Stąd zdecydował się sięgnąć po ostatnie możliwe rezerwy. Już 15 sierpnia, w dniu odwołania gen. Stopforda, poprosił gen. Maxwella o przygotowanie 2. Dywizji Konnej (2nd Mounted Division) do jak najszybszego wysłania na Półwysep Gallipoli ${ }^{58}$. Pomimo pospiechu, mogła ona dotrzeć w rejon walk najwcześniej dopiero ok. 17/18 sierpnia ${ }^{59}$.

Oczekując na przybycie 2. DK porządkowano brygady dywizji IX KA i przynajmniej częściowo uzupełniano stany poszczególnych batalionów ${ }^{60}$. 2. Dywizja Konna znalazła się w Zatoce Suvla rano 18 sierpnia i została dołączona do 10. DP jako jej trzecia brygada ${ }^{61}$. Jednocześnie dowódca dywizji, gen. William Peyton, został mianowany dowódcą 10. DP, jego miejsce zajął zaś gen. Paul Kenna. Powyższe wzmocnienia pozwoliły częściowo przywrócić możliwości ofensywne IX KA, ale wciąż były one zbyt skromne, by myśleć o sukcesie. Stąd zdecydowano się na jeszcze radykalniejsze działanie. Mianowicie 19 sierpnia dowódca 29. DP otrzymał rozkaz przygotowania swoich oddziałów do transportu w rejon Suvli, mimo, że wycofanie tej dywizji z tego odcinka frontu bardzo mocno go osłabiało. Nie był to koniec prób uzupełniania sił alianckich. Zdecydowano się także na rozpoczęcie przerzutu australijskiej 2. Dywizji Piechoty gen. Jamesa Legge' a ${ }^{62}$. Jednakże pierwsza z jej brygad, 5. BP, dotarła $\mathrm{w}$ rejon ANZAC dopiero 22 sierpnia, a pozostałe dwie brygady

oddziały, gdy te toczyły intensywne walki. Wkrótce także dowódca 53. DP, gen. John Lindley, także zrezygnował (zastąpił go gen. Herbert Lawrence, dowodzący 127. BP). Warto zaznaczyć, że gen. Hamilton jeszcze w lipcu zwracał uwagę, że oficerowie wyznaczeni na stanowiska dowódcze w IX KA byli nieodpowiedni, ze względu na brak doświadczenia i kompetencji, jego uwagi zostały jednak zignorowane przez marsz. Kitchenera, który uznał, że zasady etykiety i zwyczajów dotyczące starszeństwa powinny zostać zachowane. C.F. Aspinal-Oglander, Official History..., Vol. 2, s. 312-319; E. McGilvray, Hamilton \& Gallipoli. British Command in and Age of Military Transformation, Barnsley 2015, s. 121-122, 126; P. Hart, Gallipoli, Oxford 2011, s. 366-368.

${ }^{58}$ Dywizja składała się z czterech brygad: 1. oraz 2. South Midland Mounted Brigade, 3. Nottinghamshire \& Derby Mounted Brigade oraz 4. London Mounted Brigade. Miała ona pozostawić swoje konie na miejscu i walczyć jako formacja piesza. Ponieważ o obsługi koni należało pozostawić część żołnierzy, zdecydowano się, że zostanie ona uzupełniona dodatkową, piątą brygadą - 5 . Yeomanry Mounted Brigade. Dywizja liczyła ok. 5 tys. ludzi, i stanowiła w przybliżeniu ekwiwalent wzmocnionej brygady piechoty. Jej dowódca był gen. William Peyton.

${ }^{59}$ Mediterranean Expeditionary Force War Diary, „Q” Branch, August 1915, TNA, sygn. WO 95/4266.

${ }^{60}$ Dotychczasowe działania MEF na Półwyspie Gallipoli wskazywały, że napływ uzupełniać dla wykrwawionych batalionów z Wysp Brytyjskich był powolny i nieregularny. Stąd zdecydowano, że przed lądowaniem w Zatoce Suvla każdy z batalionów miał pozostawić na Lemnos i Imbros po 250 ludzi oraz kilku oficerów, którzy stanowić będą pierwsze uzupełniania. Dzięki temu zamierzano znacznie dłużej utrzymać zdolność bojową poszczególnych oddziałów, mimo zaangażowania w intensywne walki.

61 29. BP z 10. DP została tymczasowo podporządkowana ANZAC gen. Birdwooda.

62 Dywizja została utworzona na początku lipca 1915 roku w Egipcie z 5., 6. oraz 7. BP, które dotarły tutaj w maju-czerwcu tego roku. 2nd Australian Infantry Division War Diary, General Headquarters, June-December 1915, TNA, sygn. 95/4345. 
dopiero na początku września 1915 roku, gdy aliancka ofensywa ostatecznie się załamała $^{63}$

\section{JESIEŃ 1915 ROKU NA PÓŁWYSPIE GALLIPOLI ORAZ EWAKUACJA SIL ALIANCKICH}

W dniu 21 sierpnia wojska alianckie wznowiły działania zaczepne, ale w tym czasie wojska osmańskie już dawno zdołały wzmocnić swoje pozycje i przygotować się do odparcia spodziewanego natarcia. W rezultacie walki o Scimilar Hill oraz Hill 60 zakończyły się całkowitą klęską sił brytyjskich. W praktyce były to ostatnie większe działania zaczepne sił alianckich na Półwyspie Gallipoli. Ich fiasko spowodowało, że ponownie w Paryżu i Londynie należało podjąć decyzje, odnośnie dalszych losów kampanii.

W dniu 17 sierpnia, jeszcze przed walkami o Scimilar Hill, gen. Hamilton wysłał telegram do War Office, w którym wskazywał, że z powodu strat, jakie jego oddziały poniosły w ciągu ostatnich dwóch tygodni, kontunuowanie działań zaczepnych i zakończenie kampanii na korzyść Ententy wymagać będzie kolejnych posiłków, które szacował na ok. 95 tys. ludzi ${ }^{64}$. Kwestia dalszych losów kampania stała się tematem dyskusji Komitetu Dardanelskiego w dniu 20 sierpnia 1915 roku. W trakcie dyskusji zdecydowano, że priorytetem pozostaną działania we Francji, i tam należało skierować większość dostępnych sił i środków. W rejon Dardaneli zamierzano wysłać wszelkie możliwe uzupełnienia i posiłki, ale nie kosztem frontu zachodniego ${ }^{65}$. Ostatecznie zdecydowano, że MEF zostaną wzmocnione ok. 34 tys. ludzi, a więc ok. 1/3 liczby, o jaką prosił gen. Hamilton, nie podejmując jednak ostatecznej decyzji co do dalszych losów kampanii ${ }^{66}$.

${ }^{63}$ 5th Australian Infantry Brigade War Diary, Headquarters, March-October 1915, TNA, sygn. WO 95/4347.

${ }^{64}$ Miało być to 45 tys. ludzi potrzebnych do uzupełnienia przetrzebionych dywizji oraz 50 tys. w nowych oddziałach. From General Sir Ian Hamilton to Earl Kitchener, 17th August 1915, Directorate of Military Operations and Military Intelligence. Dardanelles, TNA, sygn. WO 106/707.

${ }^{65}$ Co ciekawe, członkowie gabinetu, w tym marsz. Kitchener bardzo pesymistycznie zapatrywali się na ewentualny sukces przygotowywanego przez francuskie naczelne dowództwo operacji zaczepnej, która przeszła do historii jako bitwy pod Loose, druga bitwa w Szampanii oraz trzecia bitwa pod Artois. Rozpoczęły się one 25 września i w ciągu kilku tygodni kosztowały wojska brytyjskofrancuskie co najmniej 200 tys. ludzi. Mimo braku wiary w ich powodzenie, zdecydowano się wesprzeć wojska francuskie ze względów politycznych.

${ }^{66} \mathrm{Na}$ tę liczbę składało się ok. 21,5 tys. ludzi jako uzupełnienia oraz pojedyncze bataliony, głównie drugoliniowe bataliony Sił Terytorialnych, jako wzmocnienie jednostek na Półwyspie Gallipoli. Ponadto ok. 12.5 tys. ludzi w jednostkach kawalerii oraz formacjach mających zabezpieczać linie komunikacyjne (bataliony wartownicze itp.) wysłanych do Egiptu, które z kolei miały pozwolić na zwolnienie jednostek liniowych i przekazanie ich do MEF; Secretary's Notes of A Meeting of The Dardanelles Comitee Held At a Hause of Commons, August 20, 1915, TNA, War Council, sygn. CAB 22/2, poz. 8, k. 39-40.

Jeszcze tego samego dnia marsz. Kitchener wysłał do gen. Hamiltona telegram, w którym informował go, że w zaistniałej sytuacji Wielka Brytania nie mogła prowadzić intensywnych operacji zarówno we Francji, jak i w rejonie Dardaneli. Ze względu na planowane ofensywy na froncie zachodnim żadne dodatkowe dywizje nie mogły zostać wysłane w celu wzmocnienia MEF, a w ciągu najbliższego miesiąca będzie mógł liczyć jedynie na uzupełnienia i niewielkie wzmocnienia w postaci wspomnianych wyżej sił; patrz: From Secretary of State for war to General Sir Ian Hamilton, 20th August 1915 (kopia telegramu w dokumentach generała G.P. Dawnaya, szefa 
Bardzo duży wpływ na ostateczną decyzję o zakończeniu kampanii na Półwyspie Gallipoli miały wydarzenia na Bałkanach. W październiku 1915 roku wojska austro-węgierskie wsparte przez oddziały niemieckie rozpoczęły ofensywę skierowaną przeciwko Serbii. Pod koniec tego miesiąca do wojny po stronie państw centralnych włączyła się Bułgaria. W rezultacie w Paryżu i Londynie zdecydowano się wysłać wojska do greckich Salonik, a jedyne źródło, skąd można było w szybkim czasie pozyskać większe siły stanowił Półwysep Gallipoli. Pod koniec września z rejonu Suvli wycofano 10. DP, którą następnie skierowano do Grecji. Po raz pierwszy siły MEF nie zostały wzmocnione, ale osłabione. Teoretycznie ubytki miały zostać w przyszłości uzupełnione nowymi dywizjami, w rzeczywistości był to początek procesu wycofywania alianckich sił z półwyspu ${ }^{67}$.

W połowie października miała miejsce także zmiana dowódcy MEF. Gen. Hamilton został zastąpiony przez gen. Charles’a Monro, który przybył w rejon Dardaneli pod koniec miesiąca $^{68}$. Po zapoznaniu się z katastrofalną sytuacją na półwyspie, rekomendował marsz. Kitchenerowi jak najszybszą ewakuację ${ }^{69}$. Początkowo rząd był niechętny takiemu rozwiązaniu, i chciał ograniczyć się jedynie do wycofania z północnych sektorów, utrzymując obecność brytyjskich sił na południu. Jednak osobista wizyta Sekretarza ds. Wojny w rejonie operacji zmieniła jego nastawienie, a pod jego wpływem także brytyjski rząd ostatecznie zgodził się na wycofanie z półwyspu, choć ostateczną zgodę wydano dopiero w grudniu 1915 roku $^{70}$. Wcześniej, rząd francuski zdecydował się na wycofanie swojego kontyngentu i wysłanie uwolnionych w ten sposób sił do Grecji ${ }^{71}$.

Sekcji Operacyjnej Dowództwa MEF (GSO2); Private Papers of G. P. Dawnay, IWM, sygn. 10403).

${ }^{67}$ C.F. Aspinal-Oglander, Official History..., Vol. 2, s. 363-376.

68 Wraz z przybyciem nowego dowódcy dokonano reorganizacji sił brytyjskich na szczeblu operacyjnym. Dywizje znajdujące się na Półwyspie Gallipoli podporządkowano nowo utworzonej Armii Dardanelskiej (Dardanelles Army), której dowódca został gen. Birdwood (na stanowisku dowódcy ANZAC zastąpił go gen. Alexander Godley). Natomiast w Grecji utworzono Armię Salonicką (Salonica Army; dowódca gen. Mahon). W tym momencie sztab MEF przestał pełnić rolę dowództwa operacyjnego ale przejął rolę koordynacyjną na tych dwóch autonomicznych obszarach operacyjnych.

${ }^{69}$ From Lieut.-General Sir C. Monro to Earl Kitchener, 31st October 1915, Directorate of Military Operations and Military Intelligence. Dardanelles, TNA, sygn. WO 106/1467.

${ }^{70}$ Już w dniu wyruszenia w drogę powrotną do Londynu marsz. Kitchener wysłał do premiera Asquitha telegram, w którym przedstawił swoją opinię na temat dalszych losów kampanii. From Earl Kitchener to Prime Minsiter, 22nd November 1915, Directorate of Military Operations and Military Intelligence. Dardanelles, TNA, sygn. WO 106/1467.

${ }^{71}$ Podejmując decyzję o wysłaniu sił do Grecji dowództwo francuskie dokonało reorganizacji własnych sił na Półwyspie Gallipoli. W październiku 1915 roku doszło do gruntownej reorganizacji wojsk francuskich na Półwyspie Gallipoli. Dotychczasowe dwie francuskie dywizje składały się z dwóch brygad każda, jednej tzw. metropolitalnej, drugiej kolonialnej. W październiku, w związku z planami wysłania części sił Korpusu Ekspedycyjnego Orientu do Salonik, zdecydowano, że zadanie to zostanie powierzone „białym” oddziałom, zaś na półwyspie pozostano jedynie wojska „kolorowe”. W związku z tym, 2. DP została ponownie przemianowana na 156. DP, a w miejsce dwóch regimentów kolonialnych (7. oraz 8. regimentu kolonialnego) zostały do niej włączone dwa regimenty z 1 . DP, mianowicie 175 . regiment piechoty oraz 1 . regiment marszowy Afryki. Jej swa regimenty kolonialne trafiły za to do 1 . DP. Dywizja ta tymczasowo wciąż nosiła nazwę 1 . DP Korpusu Ekspedycyjnego Orientu, ale w połowie stycznia 1916 roku została oficjalnie przemiano- 
Ewakuacja z północnych sektorów przeprowadzona została drugiej dekadzie grudnia 1915 roku. Pomimo obaw, udało się zaskoczyć przeciwnika, który aż do ostatnich minut nie zorientował się w trwających działaniach. W sumie od 8 do 20 grudnia ewakuowano ogółem 83048 ludzi, 186 dział, ok. 2 tys. pojazdów oraz ok. 4700 zwierząt. W przypadku IX KA z rejonu Zatoki Suvla ewakuowano 41 tys. ludzi oraz 91 dział, blisko 400 koni oraz 2300 mułów i osłów, niemal bez żadnych strat własnych, nie licząc dosłownie kilku zabitych i rannych w wyniku osmańskiego ostrzału nękającego ${ }^{72}$.

Pod koniec grudnia 1915 roku na Półwyspie Gallipoli pozostawał jedynie VIII KA gen. Davisa, złożony w tym czasie z mocno osłabionych trzech dywizji, mianowicie 42. DP, 52. DP oraz RND ${ }^{73}$. Ich stan był na tyle kiepski, że zdecydowano się ponownie uzupełnić korpus o 29. DP, która dopiero co ewakuowana została z rejonu Zatoki Suvla. Wynikało to z obaw, że zwolnione na północy wojska osmańskie zostaną skierowane na południe i wykorzystane do przeprowadzenia silnego uderzenia na siły brytyjskie. Te obawy nie były bezpodstawne. Stąd jedynym racjonalnym rozwiązaniem, pozwalającym uniknąć zniszczenia VIII KA była także jego ewakuacja. Przeprowadzono ją w pierwszej dekadzie stycznia 1916 roku. Ostatnie brytyjskie oddziały opuściły półwysep nad ranem 9 stycznia.

Między 28 grudnia a 9 stycznia ewakuowano 35 tys. ludzi, ok. 3,7 tys. zwierząt, 127 dział oraz prawie 350 pojazdów ${ }^{74}$. Choć musiano pozostawić spore zapasy zaopatrzenia, a także część dział, to kolejny raz ewakuacja zakończyła się ogromnym sukcesem. Tym niemniej, sukces ten stanowił smutne podsumowanie całej kampanii, która od początku skazana była na klęskę ${ }^{75}$.

wana na 17. Dywizję Piechoty Kolonialnej (division d'infanterie coloniale), a jej regimenty przenumerowane odpowiednio na 54., 56., 57. oraz 58. regiment piechoty kolonialnej (Régiment d'Infanterie Coloniale); Les Armes françaises dans la Grand Guerre, Tome X. Deuxime Volume, Paris 1924, s. 860-862; 992-995.

${ }^{72}$ Co warto podkreślić, oddziały IX KA nie pozostawiły ani jednego działa ani zwierzęcia, jedynie niewielkie ilości różnych zapasów zostały pozostawione w okopach. Zdołano nawet zerwać linie telefoniczne łączące stanowiska dowodzenia. Sukces ewakuacji przeszedł najśmielsze oczekiwania, gdyż na etapie planowania liczono się ze stratami mogącymi sięgać nawet 30-40\%. G.S. 637/25, 23th December 1915, IX Army Corps War Diary, General Headquarters, December 1915, TNA, sygn. WO 95/4278.

${ }^{73}$ Większość francuskiej piechoty kolonialnej została wycofana między 12 a 22 grudnia. Jedynie jedna brygada kolonialna oraz większość francuskiej artylerii wciąż pozostawała na półwyspie. Les Armées Françaises dans la Grande Guerre, Tomme VIII, Premiere Volume, Paris 1923, s. 117-125.

${ }^{74}$ C.F. Aspinal-Oglander, Official History..., Vol. 2, s. 478.

${ }^{75}$ Udana ewakuacja nie może przyćmić jednak faktu, że wielomiesięczne walki pochłonęły ogromną liczbę alianckich żołnierzy. Wg oficjalnych danych wojska brytyjskie straciły 24536 zabitych, 73357 rannych oraz 13993 zaginionych, razem 111886 ludzi (w tym 8141 zabitych i 17900 rannych żołnierzy z Australii oraz 2701 zabitych oraz 4725 rannych Nowozelandczyków). Ponadto wojska francuskie straciły ok. 3,5 tys. zabitych, ok. 17 tys. rannych oraz ok. 6,5 tys. zaginionych. Do tych danych należy dodać ok. 90 tys. chorych żołnierzy Imperium Brytyjskiego oraz ok. 25 tys. żołnierzy francuskich. Dane za: Statistics of the Military Effort of the British Empire During the Great War 1914-1920, London 1922, s. 238-239. Dane dot. Wojsk francuskich za: A. Clayton, Paths to Glory. The French Army 1914-18, London 2005, s. 210-211. 


\section{ZAKOŃCZENIE}

Kampania dardanelska miała stanowić krótki epizod i przynieść znaczne strategiczne korzyści dla Ententy. Spodziewano się, że wykorzystanie wojsk lądowych stanowić będzie jedynie ostateczność, w przypadku gdyby okrętom nie udało się przebić na Morze Marmara. Okazało się jednak, że zamiast roli pomocniczej, wojska lądowe musiały przeprowadzić pierwszą w nowoczesnej wojnie operację desantową na bronione wybrzeże. Choć udało się zająć plaże, to nie osiągnięto decydującego sukcesu, a sama kampania zamiast krótkiej ekspedycji przekształciła się w wielomiesięczne walki pozycyjne. Początkowo siły MEF składały się jedynie z 5 dywizji piechoty. $Z$ czasem ich liczba systematycznie wzrastała, by na przełomie sierpnia/września 1915 roku osiągnąć liczbę 15 dywizji zgrupowanych w czterech korpusach armijnych ${ }^{76}$.

Analiza rozbudowy MEF pokazuje, że zarówno brytyjskie, jak i francuskie kierownictwo polityczno-wojskowe nie było przygotowane na długotrwałe prowadzenie operacji lądowej w rejonie Dardaneli. Kolejne wzmocnienia kierowano w ten rejon stosunkowo przypadkowo, i wynikało to z pojawiających się możliwości niż wcześniejszego planowania. W rezultacie wzmocnienia docierały pojedynczymi dywizjami, które rzucano do walki i szybko wyczerpywano ich efektywną zdolność bojową. Ponadto brak planowości powodował, że dowodzący MEF nie był w stanie przewidzieć, jakimi siłami będzie dysponował nawet za kilka tygodni, stąd jego działania były mocno chaotyczne ${ }^{77}$.

Kolejne ofensywy prowadzono zbyt szczupłymi siłami, co stanowiło jedną z przyczyn niepowodzeń. Gdy wyciągnięto wnioski z tego działania, MEF wzmocniono znacznie większymi siłami, pozwalającymi na przewodzenie zakrojonej na szeroką skalę ofensywy. Popełniono kardynalne błędy w doborze wyższej kadry dowódczej oraz ponownie nie przygotowano natychmiastowych uzupełnień oraz rezerw operacyjnych. Stąd w momencie natrafienia na silny opór wojsk osmańskich nie było możliwości uzupełnienia wykrwawionych oddziałów ${ }^{78}$ ani podtrzymania inicjatywy poprzez skierowanie do walki odwodów. Próba wykorzystania do tego celu ściągniętej z Egiptu 2. DK oraz osłabionej 29. DP z rejonu Helles stanowiła zdecydowanie niewystarczający substytut pełnowartościowych odwodów operacyjnych. Brak planowości oraz chaos w zakresie rozbudowy potencjału MEF stanowił jeden z czynników, który ostatecznie zakończył się klęską całej kampanii.

${ }^{76}$ ANZAC (australijska 1. oraz 2. DP, NZ\&A DP, hinduska 29. BP, 4 brygady konne), CEO (francuska 1. oraz 2. DP), VIII KA (42. DP, 52. DP, RND), IX KA (10. DP, 11. DP, 13. DP, 29. DP, 53. DP, 54. DP, 2. DK). W praktyce 2. DK stanowiła ekwiwalent wzmocnionej brygady piechoty, ale jeśli wziąć pod uwagę 4 brygady konne w składzie ANZAC oraz działającą samodzielnie hinduską 29. BP, można uznać że siły te stanowiły ekwiwalent dywizji piechoty.

77 W dniu 25 kwietnia 1915 roku, w momencie lądowania na Półwyspie Gallipoli, MEF liczył 5 dywizji piechoty. W ciągu miesiąca został on wzmocniony przez kolejne 3,5 dywizji (42. DP, 52. DP, francuską 2. DP oraz hinduską 29. BP). Gdyby gen. Hamilton od początku dysponował tymi siłami, po opanowaniu plaż mógłby ich użyć do podtrzymania inicjatywy, co wobec znacznego osłabienia obrońców, dawało spore szanse na zrealizowanie pierwotnych celów operacji.

${ }^{78}$ Poza żołnierzami pozostawionymi wcześniej na zapleczu, ale trudno je uznać za klasyczne uzupełnienia, gdyż ich przygotowanie odbyło się kosztem osłabienia stanów wyjściowych poszczególnych batalionów. 


\section{LITERATURA}

1. Aspinal-Oglander C.F., Official History of The Great War. Military Operations. Gallipoli. Vol. 1. Inception of the Campaign to May 1915, Heinemann 1929.

2. Aspinal-Oglander C.F., Official History of The Great War. Military Operations. Gallipoli. Vol. 2. May 1915 to the Evacuation, London 1931.

3. Bean C.E.W., Official History of Australia in the War of 1914-1918, Vol. 1. The Story of ANZAC from the outbreak of war to the end of the first phase of the Gallipoli Campaign, May 4, 1915, Canberra 1941.

4. Broadbent H., Gallipoli. The Fatal Shore, Camberwell 2009.

5. Carlyon L.A., Gallipoli, London-New York-Toronto-Sydney-Auckland 2001.

6. Cassar G.H., Kitchener's War. British Strategy From 1914 to 1916, Washington 2004.

7. Churchill W., The World Crisis, Vol. 2. 1915, London, New York 2015.

8. Clayton A., Paths to Glory. The French Army 1914-18, London 2005.

9. Coleman E.C., Khaki Jack. The Royal Naval Division in The First World War, Stroud 2014.

10. Curran T., The Grand Deception. Churchill and the Dardanelles, Newport 2015.

11. Erickson E.J., Gallipoli. Command Under Fire, Oxford 2015.

12. Gillonn S., The Story of 29th Division. A Record of Gallant Deeds, London, Edinburgh, New York 1925.

13. Hamilton I., Gallipoli Diary, Vol. 1, New York 1920.

14. Hart P., I wojna światowa 1914-1918. Historia militarna, Poznań 2013.

15. Korzeniowski P., Charakterystyka alianckich sit ladowych bioracych udziat $w$ desancie na Pótwyspie Gallipoli 25 kwietnia 1915 roku [w:] O powinnościach żotnierskich, t. III, pod red. A. Drzewieckiego, Oświęcim 2016.

16. Korzeniowski P., Przygotowania do lądowania sit alianckich na Pótwyspie Gallipoli 25 kwietnia 1915 r. [w:] Człowiek i technika na polach bitew wojen światowych, pod red. A. Olejko, P. Korzeniowskiego, Rzeszów 2016.

17. Laffin J., The Agony of Gallipoli, Oxford 2005.

18. McGilvray E., Hamilton \& Gallipoli. British Command in and Age of Military Transformation, Barnsley 2015.

19. Middlebrook M., Your country needs you. From six to sixty-five divisions, Barnsley 2000.

20. Nykiel P., Wyprawa do Złotego Rogu. Działania wojenne w Dardanelach i na Morzu Egejskim (sierpień 1914-marzec 1915), Kraków 2008.

21. Rawson A., The British Army 1914-1918, Stroud 2014.

22. Simkins P., Kitchener's Army. The Rising of the New Armies 1914-1916, Barnsley 2007.

23. Thompson R.R., The Fifty-Second Lowland Division 1914-1918, Glasgow 1923.

24. Van Der Vat D., The Dardanelles Disaster. Winston Chuirchil's Greatest Failure, LondonNew York 2009. 


\title{
THE PROCESS OF EXPANSION OF THE MEDITERRANEAN EXPEDITIONARY FORCE (MEDITERRANEAN EXPEDITIONARY FORCE) IN 1915
}

\begin{abstract}
The Dardanelles campaign was intended as to be a short episode and brought significant strategic benefits to the Entente. It was expected that the use of ground troops would be only the last resort, in case the warships failed to break through to the Sea of Marmara. It turned out, however, that instead of an auxiliary role, the land forces had to carry out the first in the modern warfare landing operation on the defended coast. Although they managed to capture the beaches, they failed to occupy the crucial objectives. The campaign instead of a short expedition was transformed into a multi-month position fight. Initially, the MEF forces consisted of only 5 infantry divisions. With time, their number systematically increased, and between August and September it reached the number of 15 divisions grouped in four army corps.

Reinforcements were directed to this area of operations circumstantially, mostly due to the emerging possibilities than earlier planned. As a result, the additional divisions were thrown into battle and quickly their effective combat capability were diminished. After a few months, the conclusions were drawn from these actions, and the MEF was strengthened by a much greater force, allowing it to conduct a wide-scale offensive. But other cardinal errors were made, primarily in the selection of senior command staff. Moreover, immediate replenishments and operational reserves were again not prepared. Lack of planning and chaos in the development of MEF's potential was one of the key factors that finally ended in the failure of the entire campaign.
\end{abstract}

Keywords: Gallipoli Campaign, Dardanelles, British Army, World War I.

DOI: $10.7862 /$ rz.2018.hss.24

Przestano do redakcji: styczeń $2018 r$.

Przyjęto do druku: czerwiec 2018 r. 
